\title{
Systematic review and meta-analysis of the predictive value of C-reactive protein in postoperative infections
}

\author{
BK Nunes,, RA Lacerda, JM Jardim \\ From International Conference on Prevention \& Infection Control (ICPIC 2011) \\ Geneva, Switzerland. 29 June - 2 July 2011
}

\section{Introduction / objectives}

Systematic review and meta-analysis on C-reactive protein (CRP) to determine its value in predicting prognosis / diagnosis of infection in surgical patients.

\section{Methods}

The sources were searched: Cochrane, Embase, Lilacs, Pubmed / Medline, Ovid, and references of studies found. Was used the PICO strategy for the definition of descriptors. The data of the studies were obtained through a systematic instrument, and the strength of evidence was classified according to the Center for Evidence Based Medicine. For the statistical analysis software was used Meta- Disc version beta 1.1.1 (freeware).

\section{Results}

20 studies were included, 18 classified with the highest level of evidence. All reported elevated levels of CRP after surgery and in the presence of postoperative infections (PO), 8 studies a peak CRP between the 2nd and 3rd postoperative day was reported as a normal curve of CRP declined for patients without complications postoperatively, and rising in patients with complications. In four studies it was observed that a value greater than 5 $\mathrm{mg} / \mathrm{dl}$ in the postoperative CRP is indicative of infection. And the patients with levels above $140 \mathrm{mg} / \mathrm{dl}$ in the 4th OP are more likely to develop infections. The meta-analysis revealed a mean of $85 \%$ (sensitivity), $86 \%$ (specificity), the area under the SROC curve was 0.9060 , and odds ratio was 23.56 .

University of São Paulo, São Paulo, Brazil

\section{Conclusion}

CRP, together with other clinical interventions, has high value in the prognosis / diagnosis in the development of postoperative infection.

\section{Disclosure of interest}

None declared.

Published: 29 June 2011

doi:10.1186/1753-6561-5-S6-P29

Cite this article as: Nunes et al: Systematic review and meta-analysis of the predictive value of $\mathrm{C}$-reactive protein in postoperative infections. BMC Proceedings 2011 5(Suppl 6):P29.

Submit your next manuscript to BioMed Central and take full advantage of:

- Convenient online submission

- Thorough peer review

- No space constraints or color figure charges

- Immediate publication on acceptance

- Inclusion in PubMed, CAS, Scopus and Google Scholar

- Research which is freely available for redistribution 